Volume 18 Number 2 December 2018. p 417-435

https://doi.org/10.30603/au.v18i2.610

\title{
Wahdah Islamiyah's Counter-Radicalism Strategy Through The New Media Network in Da'wah Development of Palu City
}

\author{
Muhammad Khairil
}

Tadulako University, Palu, Central Sulawesi, Indonesia

\begin{abstract}
Radical labels and terrorist movements are often pinned down on various Islamic organizations in Indonesia, one of which is Wahdah Islamiyah (WI). This stigma is growing rapidly among Indonesians because the news in the media seems to accuse Islamic organizations of being the source of radical movements. Understanding the media becomes a crucial need in society. In addition, Islamic organizations are required to balance technological developments and utilize communication media in the modern era to re-establish the image of Muslims in Indonesia. This study focused on Wahdah Islamiyah in Palu City and was carried out with qualitative methods and case study approach to see and explain how the Wahdah Islamiyah in Palu City understood and utilized the media in responding to radical ideas that were often attached to Islamic organizations. This research shows that WI has a special strategy in responding to radicalism and has been able to utilize online media even though it is not yet optimal.
\end{abstract}

\begin{abstract}
Abstrak
Label radikal dan gerakan teroris kerapkali disematkan pada berbagai organisasi Islam di Indonesia, salah satunya adalah Wahdah Islamiyah (WI). Stigma ini berkembang pesat di kalangan masyarakat Indonesia dikarenakan pemberitaan di media yang seolah-olah menuduh organisasi Islam sebagai sumber dari gerakan radikal. Melihat hal tersebut, pemahaman media menjadi sebuah kebutuhan yang krusial di masyarakat. Selain itu, organisasi Islam diharuskan untuk mengimbangi perkembangan teknologi dan memanfaatkan media komunikasi di era modern untuk kembali membangun citra ummat muslim di Indonesia. Penelitian ini terfokus pada Wahdah Islamiyah Kota Palu dan dilakukan dengan metode kualitatif serta mengaplikasikan pendekatan studi kasus untuk melihat dan menjelaskan bagaimana organisasi Islam Wahdah Islamiyah Kota Palu memahami serta memanfaatkan media dalam menanggapi paham radikal yang kerap melekat pada organisasi Islam. Penelitian ini menunjukkan bahwa WI memiliki strategi khusu dalam menanggapi radikalisme dan telah mampu memanfaatkan media online meskipun belum maksimal.
\end{abstract}

Keywords: Radicalism; Media Utilization; Da'wah

Author correspondence

Email:mkhairil@untad.ac.id

Available online at http://journal.iaingorontalo.ac.id/index.php/au/index 


\section{A. Introduction}

The rise of the development of radicalism in Indonesia, which is said to spread through religious organizations, has led to increasingly negative assumptions that Islamic organizations play a big role behind it all. The notion of radicalism was later linked to acts of terror and suicide bombings. Worse, the terrorists were caught on camera and reported throughout the mass media to social media, as individuals who use Islamic identity, such as robes, caps, beards, even hijabs ${ }^{1}$. As a result, Islam was the target of all the news that emerged between the issues of radicalism and terrorism.

The accusation tendency on certain Islamic groups with radicalism are considered as opposing the existence of the Unitary State of the Republic of Indonesia ${ }^{2}$. No doubt, the radical accusation was aimed at Islamic organizations which were considered to want to Islamize Indonesia, and were accused of not being nationalist.

The way of Islamic Organization reacts to the news and accusation also become a focus of the community. Many Islamic organizations that wildly reacts to the accusations made by the mass media can be classified as adding fuel to the fire, in which makes the organizations are labelled as dangerous. The accusation is inseparable from the media coverage, which is sometimes very fixated on pursuing news without thinking about journalistic ethics and manners ${ }^{3}$. The radical and terrorists labels that are often embedded in the body of Islamic organizations causes the movement and development of the organization to be hampered ${ }^{4}$. People are increasingly moving away from Islamic organizations due to fears and stigma that are embedded from the coverage of various media.

\footnotetext{
${ }^{1}$ Nurzihan Hassim, "Hijab and the Malay-Muslim Woman in Media," Procedia - Social and Behavioral Sciences 155, no. October (2014): 428-33, https://doi.org/10.1016/j.sbspro.2014.10.317.

${ }^{2}$ Muhammad Khairil et al., "Understanding Terrorism Based On Radicalism Idea In Order To Avoid Instability For Achieving Environmental Peace And Justice The Sustainable Development Goals (SDGs)," Journal of Food, Agriculture \& Environment 15, no. I (2017): 48-51.

3 Muhammad Khairil et al., "Mass Media Coverage on Terrorism in Order to Achieve Peace and Justice According to the World Agenda of Sustainable Development Goals (SDGs)," INFORMATION 20, no. 7 (A) (2017): 4935-40.

4 Kamaruzaman Yusoff, "Islamic Radicalism in Malaysia: An Overview" 5 (2010): 2326-31, https://doi.org/10.1016/j.sbspro.2010.07.458.
} 
Media monetization that occurs makes a qualified understanding of the media, especially online media, as a requirement that must be mastered by the community 5 . In addition, the shift in the pattern of communication of the community, especially teenagers/young adults to social media, has made Islamic organizations required to pursue technological developments in carrying out da'wah and deradicalization efforts.

\section{B. Social Media as a New Gate of Human Interactions}

The development of mass communication technology has progressed very rapidly. The advancement in technology has brought humanity more easily to connect with one another. Communication has reached a level where people are able to talk to millions of people instantenously and simultaneously.

This is in line with what was stated by Emil Dofivat, that since 1964 mass communication has reached the world public directly and simultaneously ${ }^{6}$. Through communication satellites as today, theoretically, media will be able to show pictures and sounds to three billion people worldwide simultaneously. Communicators only need to connect the transmitter and millions of people just have to set up the receiver. Technically this has long been done but what remains to be debated is which communicator should communicate and what images should be shown.

The development of human civilization was accompanied by the development of ways of delivering information (which was later known as Information Technology). Starting from the images engraved on the cave walls as a milestone in the form of inscriptions until the introduction of the world of virtual information and communication flows which became known as the internet?

Media is one of the development of science and technology results, as a form of human mastery of the sunnah which controls nature. Its existence in human life has social implications, which also relate to sunnatullah which control

\footnotetext{
5 Iain S. Weaver et al., "Dynamic Social Media Affiliations among UK Politicians," Social Networks 54 (2018): 132-44, https://doi.org/10.1016/j.socnet.2018.01.008.

${ }^{6}$ Jalaluddin Rakhmat, Psikologi Komunikasi (Bandung: Rosdakarya, 2015).

7 Rusman, Pembelajaran Berbasis Teknologi Informasi Dan Komunikasi (Jakarta: RajaGrafindo Persada, 2015).
} 
human life as social beings. The study of the existence and urgency of media is the science of communication ${ }^{8}$.

Mass communication has a function to provide information, education, and entertainment, also to influence people. The process of mass communication will have an effect on the reader, listener or the audience in general, so that the effect creates a difference between what is thought, felt and done by the recipient before and after receiving the message 9 .

Each components of communication (communicator, message, media) are very powerful in influencing communication. It is called a hypodermic needle because in this model it is suggested that communication is injected directly into the communicant's mindset. As drugs are stored and distributed in the body so that changes occur in the physical system, the persuasion messages change the psychological system so that behaviorism greatly influences this theory.

The communicator variable is indicated by credibility, attractiveness and power. Credibility consists of two elements, expertise and honesty. Expertise is measured by the extent to which the communicant considers the communicator to know the correct answer, while honesty is rationalized as the communication perception about the extent to which the communicator behaves impartially in conveying his message. Attractiveness is measured by similarity, familiarity and preferences. Power is rationalized by communicant responses about the ability of communicators to reward and the ability to examine communicants is submissive or $\operatorname{not}^{10}$.

Message variables consist of message structure, style, and appeals. The message structure is addressed by the pattern of inference (implied or explicit) and the pattern of objectivity (one or two sides). Message style shows linguistic variation in message delivery (repetition, ease of understanding and vocabulary). The message appeals to the psychological motives contained in the message (emotional ratios etc.) ${ }^{11}$.

\footnotetext{
${ }^{8}$ Anwar Arifin, Dakwah Kontemporer Sebuah Studi Komunikasi (Yogyakarta: Graha Ilmu, 2011).

9 O. U. Effendy, Ilmu Komunikasi : Teori Dan Praktek (Bandung: Remaja Rosdakarya, 2011).

${ }^{10}$ Ibid.

11 Ibid.
} 
Media variables can be electronic medias, printed medias or interpersonal channels (lectures, discussions and so on). The intermediate variable is aimed at attention in which the communicant is aware of the message. The understanding is measured by the extent to which the communicant understands the message. The acceptance is limited by the extent to which the communicant agrees with the ideas expressed by the communicator. Effect variables are measured in terms of cognition (change of opinion, addition of knowledge and trust), aspects of affection (attitudes, preferences) and behavioral aspects ${ }^{12}$.

This model is often also called bullet theory because the communicant is considered a passive side that receive a barrage of communication messages. When using the right communicator, a good message, the right media, then the communicant can be directed at the will of the communicator. DeFleur call it the mechanistic S-R theory ${ }^{13}$.

The effect that is generated on the human self in the process of mass communication occurs in three aspects ${ }^{14}$ : the cognitive aspect, where the effects that arise on the communicant causing understanding or intellectual increase; affective aspects, where the effects of mass communication are higher than cognitive; and behavioral aspects, where the effects that arise on the communicant in the form of behavior, actions or activities ${ }^{15}$.

\section{Labelling Construction on the Indonesian's Muslims}

labeling or embedding labels is a form of symbolic interaction. The labeling or embedding of these labels becomes negative when the pinned labels fall into the category of characters that are contrary to social norms. Labeling theory has two propositions: deviant behavior is not a resistance to the norm, but a variety of behaviors that are successfully defined or dubbed deviant, where deviant or deviation itself is not inherent in the action itself but is a response to others in

\footnotetext{
12 Ibid.

13 Ibid.

14 Ibid.

15 Hanifi Kurt, "Acritical Review to the Media Which Constructed in Media Literary Course in Secondary Education," Procedia - Social and Behavioral Sciences 174 (2015): 711-19, https://doi.org/10.1016/j.sbspro.2015.01.606.
} 
acting and deviations are said to exist in the seeing eye; labeling itself generates or strengthens deviations, in which the response of people who deviate from social reactions produces secondary deviations which they obtain self-image or selfdefinition as someone who is permanently locked into the role of a deviant person. Deviation is an outcome or a result of social errors and the use of social controls ${ }^{16}$.

The Muslims are among the majority among the entire population of Indonesia. However, Indonesian Muslims often get a negative view. Especially with the number of events and incidents based on religious symbols. The number of radical Islamic movements in the form of terrorism also has a major impact on how the Muslims are viewed by the general public, especially the world ${ }^{17}$.

Labeling among the general public has had a number of serious consequences. The labeling effect will be far greater in the audience if intensified enough through mass media. Mass media narratives point out that certain groups of people have certain characteristics and show certain behaviors that lead to the interpretation that they are against the government ${ }^{18}$, internalized by the audience and assumed to be the reality. Thus, the media audience will construct the meaning in the process of receiving messages according to the results of media construction. Deviation theory considers deviance not as a set of individuals or groups, but rather a process of interaction between deviant and non-deviant.

In every movement, the Islamic organization certainly has its own ideology. An ideology, according to Edwar Shils, is understood as a product and human effort to create an intellectual order about the world and as an intensification of human needs for cognitive and moral maps that must be achieved and born in crisis conditions in various sectors of society who cannot accept the current view of life ${ }^{19}$.

\footnotetext{
${ }^{16}$ Keon West and Joda Lloyd, "The Role of Labeling and Bias in the Portrayals of Acts of 'Terrorism': Media Representations of Muslims vs. Non-Muslims," Journal of Muslim Minority Affairs 37, no. 2 (2017): 211-22.

17 Muhammad Khairil, "The Transformation of the Symbolic Meaning of Radicalism in Acts of Terrorism Post-Conflict in Poso Central Sulawesi," in International Conference on Democracy, Accountability and Governance, 2017, 282-89.

18 Indiwan Seto Wahjuwibowo, Terorisme Dalam Pemberitaan Media (Yogyakarta: Deepublish, 2015).

${ }^{19}$ Amin Rais, Cakrawala Islam (Bandung: Mizan, 1999).
} 
Various diversity of thoughts that can generally be seen from the labeling and discourse that developed in the community, including Radical-Fundamental Islam who are dissatisfied with perceived modernization that can shift religious values and their implementation in people's life. Normative Theological Islam is a Islam teaching that believe the revelation solely comes from God, must be believed, accepted as absolute truth that must not be contested. Exclusive Islam is an attitude that views the beliefs, views, thoughts and self-righteous as absolute truth so that they do not accept suggestions and thoughts from other Islamic point of views $^{20}$.

In Indonesia, this tension can be seen from the polarization put forward by three groups who have a fairly strong mass base. First, Islamic traditionalism that flourished since the beginning of the entry of Islam into Indonesia. Islamic traditionalism has Islamic thoughts that are still strongly tied to the thoughts of Islamic hadiths, tasauf, tafsir and tauhid that lived between the seventh and thirteenth centuries. Second, modernists generally have a base in urban areas, where people tend to be more open and accept new ideas. The basic vision of modernists is the purification of Islam by eradicating everything that reeks of khurafat and bid'ah, breaking away from the bonds of the mazhab and reopening the doors of ijtihad. Third, fundamentalists which have a base of urban middle groups and generally are formally educated. As explained earlier that fundamentalism is a people who are dissatisfied with modernization which felt shift religious values and their implementation in people's lives. Fundamentalists offer Islamic concepts in a transparent manner. The idea of a totalistic Islam that lasts and complete which covers all fields of social, political, economic life, and covers aspects of individual and collective life ${ }^{21}$.

One thing that is difficult to avoid in the dynamics of diversity of religious thought is tension and even conflicts that arise along with the development of these thoughts. On one hand, tension arises from the necessity of maintaining the

\footnotetext{
${ }^{20}$ H. Abuddin Nata, Peta Kerangka Pemikiran Islam Di Indonesia (Jakarta: Raja Grafindo Persada, 2001).

${ }^{21}$ Muhammad Khairil, "Pluralisme, Toleransi Dan Budaya Komunikasi Ummat Beragama," Jurnal Inspirasi MKDU Untad, no. 3 (2007): 25.
} 
doctrinal aspect of religious norms in an ever-changing world situation. While on the other hand tension is born by a sociological process ${ }^{22}$.

\section{The Urgency of the Modern Era Da'wah}

Islamic history records that the duties and obligations of preaching or $d a^{\prime} w a h$ were initially imposed on Rasulullah and his followers as stated in the Qur'an surah Al-Maidah, verse 67, O Messenger convey what was revealed to you from your Lord and if you did not (what commanded) you do not deliver His message and Ali Imran verses 103-104, And let among you there be a group of people who call on virtue, call upon those who speak and prevent from the wrong, they are the lucky ones.

On the communication aspect, it is clear that da'wah is a communication effort in order to influence individuals or groups so that they consciously believe in Islam, want to adhere to it (for non-Muslims) and deepen their knowledge of Islam (for Muslims). They were expected to believe that Islam would bring them to the righteous way of Allah, namely the path which is a meaningful line and was afforested in the guidance of absolute truths of revelation, therefore communication in this viewpoint was better known as Islamic preaching or da'wah Islamiah $^{23}$.

Thus the da'wah process is inseparable from the communication paradigm except that the ultimate goal of $d a^{\prime} w a h$ is to change the nature, attitudes, opinions and behavior of communicants into Islamic beings. In other words, the purpose of da'wah is to form a civilized Islamic society. While the ultimate goal of free communication according to the wishes of the communicator.

The Islamic press, as part of the indigenous press aimed at spreading the spirit of nationalism and the ideals of independence, initially appeared as a partisan media, because of the tendency to spread the ideology of its publishing group. But after the reformation was opened at the end of 1997 and the 1998, the existence of the Islamic press became more widespread, both as a propaganda

\footnotetext{
22 Pompiliu Alexandru, "A Semiotic Analysis of the Expression of Antithetical Emotional States," Procedia - Social and Behavioral Sciences 149 (2014): 31-36, https://doi.org/10.1016/j.sbspro.2014.08.174.

23 Arifin, Dakwah Kontemporer Sebuah Studi Komunikasi.
} 
media and as a forum for resistance to the regime ${ }^{24}$. This is what triggers the growing development of the Islamic press in Indonesia.

The Islamic press as a media of propaganda, of course, is not limited to the side of mere interests. Given the many layers of culture, culture and religion in Indonesia, the Islamic Press tends to adjust to its market. Today there is no visible Islamic Press that truly reflects Islamic values in full, both in terms of packaging and contents. Regardless of packaging or display, the existence of the Islamic press as a medium of propaganda has more or less played an active role in shaping the character of the Indonesian people ${ }^{25}$. And the Islamic press here is not only carried out by people who are simply going there, for example pesantren, ulama, etc. However, many people or institutions that are not too focused now publish their names as Islamic press. Staying here we must limit, which one does bring the interests of Muslims and what does not. In a sense, avoid the Islamic press which is only oriented to business and market interests only ${ }^{26}$.

Da'wah can be defined as the dissemination of teachings or understandings, and the media is a means of disseminating it. So the $d a^{\prime} w a h$ media is a tool for disseminating teachings or understandings. Thus, the packaging must be truly acceptable to readers who in fact have many choices to choose which media should be consumed. In that sense, the Islamic press as a media of $d a^{\prime} w a h$ must be able to attract the sympathy of its market, by certainly not giving up its vision and mission as a medium of propaganda 27 .

The teachings of Islam provide an opportunity for everyone who is inhumanely treated (zhalim) to hold resistance in self-defense. In fact, if the person concerned wants to repay the crime of that person even the religion justifies it, provided that it is equal to the crime he has received. Replying to crimes with the same crime is not subject to sanctions of sin, because sin only applies to those who do wrong (zhalim) without resting on the logic of truth.

In Islamic view, the religion arise from human discovery of truth, beauty and goodness ${ }^{28}$. The first man who was commanded by God to come down to earth,

\footnotetext{
${ }^{24}$ Rais, Cakrawala Islam.

${ }^{25}$ Kurt, "Acritical Review to the Media Which Constructed in Media Literary Course in Secondary Education."

${ }^{26}$ Rais, Cakrawala Islam.

27 Khairil et al., "Mass Media Coverage on Terrorism in Order to Achieve Peace and Justice According to the World Agenda of Sustainable Development Goals (SDGs)."

${ }^{28}$ Rais, Cakrawala Islam.
} 
was given a message to follow his instructions. The first clue to give birth to the religion was when Adam on his journey on earth discovered truth, beauty and kindness.

\section{E. Wahdah Islamiyah: a Da'wah and Educational Effort}

This organization was founded on June $18^{\text {th }}, 1988$ under the name Fathul Muin Foundation, based on the notary deed of Abdullah Ashal, S.H. No. 20. To avoid the impression of an individual cult towards KH Fathul Muin Dg. Mangading, a charismatic figure head of South Sulawesi who in his lifetime became the coach of the founders of Fathul Muin Foundation, so that could become the Institute of Unity of the Ummah. On February 19th 1998 , the name Fathul Muin Foundation changed to the Wahdah Islamiyah Foundation, which means Islamic Unity. The name change was formalized based on the notary deed of Sulprian, S.H. No. 059.

In connection with the plan to establish an Islamic tertiary institution, Wahdah Islamiyah Foundation added a word to its identity to become the Wahdah Islamiyah Islamic Boarding School Foundation which was intended to be able to also house higher education institutions, based on Notary Deed of Sulprian, S.H. No.055 dated May 25th 2000.

The rapid development of Wahdah Islamiyah's da'wah makes it impossible for this Islamic institution to move in the form of a foundation. Thus, in the 2nd Wahdah Islamiyah Islamic Boarding School Foundation conference on $1^{\text {st }}$ Shafar 1422H (April 14th 2002 ) was agreed to establish mass organizations with the same name, namely Wahdah Islamiyah. Since then, Wahdah Islamiyah Islamic Boarding School Foundation, which is the forerunner of the establishment of Wahdah Islamiyah, has been simplified as an institution that manages Wahdah Islamiyah's formal education.

Wahdah Islamiyah is an Islamic Mass Organization which bases its understanding and understanding on the Qur'an and the Sunnah according to the understanding of As Salaf Ash-Salih (Manhaj Ahlussunnah Wal Jamaah). This organization is engaged in the fields of $d a^{\prime} w a h$, education, social, femininity, information, health and the environment.

This study applies a qualitative approach using the case study paradigm to see and explain how Wahdah Islamiyah Islamic organizations understand and 
Wahdah Islamiyah's Counter-Radicalism Strategy Through The New Media Network in Da'wah Development of Palu City

utilize the media in response to radical ideas that are often inherent in Islamic organizations. This study focuses on Wahdah Islamiyah in Palu City. The data collection technique that was applied in this study originated from initial observations. Data obtained from the initial observations were then dug deeper and confirmed by conducting in-depth interviews with management and members of Wahdah Islamiyah Palu. The collected data is then grouped into several categories for data reduction. The results of this data reduction are then analyzed and finally conclusions are drawn.

\section{F. Digitized Da'wah: the Use of New Media to Counter Radicalism}

Wahdah Islamiyah, an organization that often accused of being part of a terrorist network such as the news on MetroTV in 2016, made social media (Facebook and Fanspage accounts) as a means used by to inform their $d a^{\prime} w a h$ activities such as ta'lim, daurah, and others. Almost every day there are always posts with quite interesting designs, which are packaged in a contemporary style but still refer to the pattern established by the Information and Communication Board of the Wahdah Islamiyah Central Executive Board. Thus, pamphlets, leaflets, flyers, and others have certain characteristics.

To accelerate and expand the spread of $d a^{\prime} w a h$ on social media, Wahdah Islamiyah Palu posted an agenda of activities in groups that have many members, assisted by the dissemination of information by cadres on their personal accounts. The dissemination of this information is more focused through Whatsapp, because according to the Wahdah Islamiyah Palu management itself, this media is able to directly and quickly contact the community. In addition to the Facebook and Fanspage of The Regional Branch, Wahdah Islamiyah's da'wah efforts on social media is also distributed by muslimah accounts of Wahdah Islamiyah.

Wahdah Islamiyah is not only trying to preach through the media with their personal accounts, but also collaborating with the central management on the wahdah.or.id website by sending raw information about the activities carried out by Palu City's Regional Branch to be processed and posted on the website as news. Based on the results of interviews with Wahyuni, one of the management of Wahdah Islamiyah Palu which was carried out on November $23^{\text {rd }}$, 2018, it was confirmed that Wahdah Islamiyah Palu's cadres did not yet have adequate skills in 
journalism, although many cadres were able to write posts, as evidenced by posts on personal accounts, but in terms of news writing, the cadres still cannot distinguish between a mere caption and interesting news content that can be published to the media.

With all the limitations of social media understanding, particularly Facebook and Fanspage, the Palu City's Regional Branch of Wahdah Islamiyah is able to attract the attention of many people, especially at grand events. This interest is evidenced by the number of participants, even atract many finansial donors. Based on the observation, the success was supported by an interesting pamphlet model and the enthusiasm of the management and members to share the post, for example in Fanspage (September 28 $8^{\text {th }}$ Post) which was shared 180 times, not including those who shared the previously shared content.

However, the dissemination of information to personal accounts, even though it has been recommended and in some activities/content is indeed shared enthusiastically, the results have not been maximized and the attention is focused only on certain content. Cadres, especially administrators, are more focused on their personal content than by intensely publishing event contents. On the other hand, Wahdah Islamiah Palu also has not assigned one administrator to become a permanent social media admin. So far, the social media that is managed by several administrators as an admin that in alternate turns.

In the future, Wahdah Islamiyah Branch of Palu will try to intensify da'wah campaigns on social media, so that it does not only contain posts about the events or routine studies. Because da'wah in the media, according to Wahyuni, is an extraordinary thing.

Media has an important role, meaning that if we can master the media, especially in the digital age, by God, it can provide enlightenment or the formation of positive opinions about Islam, which are always cornered, so that the news is more balanced. Because if we choose to remain silent, news in media such as newspapers and digital media, becomes unbalanced. Sometimes, many have lost confidence in big media, as this era is rather liberal in writing news, so there can be no balance achieved. For us, Wahdah Islamiyah is especially able to take on this role, God willing, we are able to provide a balance in the news (Interview, 28 November 2018).

Examined from the social media of the Wahdah Islamiyah Regional Branch of Palu, the da'wah development is fairly developed compared to other Islamic 
Wahdah Islamiyah's Counter-Radicalism Strategy Through The New Media Network in Da'wah Development of Palu City

organizations in Palu. In routine posts, the Regional Branch has obliged all administrators to take part in distributing existing posts, even though they are not officially written. Regarding radicalism news, personally, Wahyuni has never read directly in print media, except for the news broadcasted on Metro TV in 2016, and has been clarified both by Wahdah Islamiyah and Metro TV,

Wahdah Islamiyah Palu is not too reactive in addressing the issue, because it has been resolved by the higher ups. Not only in solving problems in 2016, but there are new issues arise, the decision is not to spread the issues. These issues were analyzed first internally, then processed. If indeed it needs to be addressed, the highest level or the central management responds first, while the Regional Branches are waiting for instructions. This pattern is done to minimize a wild pattern, which everyone has the right to respond to.

Actually, Wahdah Islamiyah has made special efforts, but is more focused at the central level. In addition to clarifying, the Wahdah Islamiyah also wrote several writings explaining to the public, that Wahdah Islamiyah is not radical. Of course this is to counterbalance the news. On the wahdah.or.id website, there are many counter-radical writings posted.

Although its members have quite intense media exposure, among Wahdah's cadres, especially Wahdah Islamiyah Palu, the urge for reading or opening links on the website is still lacking, even though nationally the number of Wahdah's cadres is considered big. But because of reading interest and lack of awareness of the importance of $d a^{\prime} w a h$ in the media, content, articles or news coverage of Wahdah Islamiyah are lost on search engines because the content is created without thinking of SEO-friendly patterns.

The use of online media as a medium of da'wah should be able to open a new gate for the Islamic development, especially for Indonesian Muslims. The lost of the Wahdah Islamiyah webpage on search engines proves that even though the tool is readily available, the expected results will not be achieved if it is not optimally used. Not applying the SEO-friendly pattern in the construction of web pages also causes a loss by other media ${ }^{29}$.

${ }^{29}$ Khairil et al., "Mass Media Coverage on Terrorism in Order to Achieve Peace and Justice According to the World Agenda of Sustainable Development Goals (SDGs)." 
The opening of the globalization era should also be utilized by the Muslim to increase the creativity they have ${ }^{30}$. In fact, many Muslims only become passive inhabitants of the glorious cyberspace. Only a few Muslims, especially the Indonesian Muslim community, actively use online media to hone and preach using the creative work they have created ${ }^{31}$. In this aspect, Wahdah Islamiyah needs to increase the capacity of its members in response to media exposure so that members of Wahdah Islamiyah, especially Regional Branch of Palu, are not only become passive connoisseurs of online media.

\section{G. The Transformation of Islamic Symbols: an Effort to Counter Radical Label}

Wahdah Islamiyah, branded as radical not only in the news but also both online and social media. Directly, the organization received accusations from the community as a radical group for several reasons, one of which was the way women dressed. In the past years, the Wahhah Islamiyah akhwat always wears dark colors, dominantly in black, when attending the assembly or was in the community. The way to dress dominantly with black is often related to radicalism. Thus, it creates a stigma that Wahdah Islamiyah is a radical group, even a part of terrorist networks, especially by the general public.

The label has been constructed in such a way by the news in the mass media that it is imprinted on the people's mindset. The symbols of the Muslim which can be seen directly such as outwear become their own identification which results in a variety of negative attitudes. Not only attitudes in the real world, but also occur in cyberspace forums that even more frontal when compared to the attitudes in the real world. This attitude, better known as Islamophobia, blatantly decomposes in cyberspace due to the high level of online media anonymity ${ }^{32}$.

\footnotetext{
30 Lavinia Suciu and Simona Simon, "Informing Strategies: Building the Communication Framework," Procedia - Social and Behavioral Sciences 197, no. February (2015): 1246-49, https://doi.org/10.1016/j.sbspro.2015.07.392.

31 Saskia Warren, "Placing Faith in Creative Labour: Muslim Women and Digital Media Work in Britain," Geoforum 97, no. October (2018): 1-9, https://doi.org/10.1016/j.geoforum.2018.10.003.

32 Anton Törnberg and Petter Törnberg, "Muslims in Social Media Discourse : Combining Topic Modeling and Critical Discourse Analysis," Discourse, Context and Media 13 (2016): 132-42, https://doi.org/10.1016/j.dcm.2016.04.003.
} 
Wahdah Islamiyah's Counter-Radicalism Strategy Through The New Media Network in Da'wah Development of Palu City

However, when the radical issue plagued and attacked a number of Islamic organizations, Wahdah Islamiyah immediately made a decision. For example, when the dominantly black outwear is associated with radical terrorist movements, the Wahdah Islamiah's akhwat is ordered directly from the Central management to look more colorful, or wear brightly colored clothes. This was done so that Wahdah Islamiyah's da'wah was more integrated with the community. This decision is carried out also to convey to the public that Wahdah Islamiyah is not as radical as the media intended and its news ${ }^{33}$. This specific instruction was confirmed by Wahyuni at the interview.

Because the cadres are dressed not paying attention to the community's stigma, there is an appeal to wear clothing with more colorful tones, to make them more unified. They are very happy and passionate about learning, so they wear acceptable clothes. But the community does not necessarily respond to it well. For example, they gathered at the discussions and they wore black. Obviously it will be the center of attention and is considered to bring another misunderstanding. Especially for veiled women. To dress like that affects Wahdah Islamiyah's preaching in the community. It is not surprising if the organization was criticized as radicals. Related to this, the central higher ups had warned and urged to use clothing that is not all black, so that people out there are not prejudiced against the organization to avoid slander, negative views and accusations. This appeal was started at the Congress in Jakarta. (Interview with Wahyuni, November 28th 2018).

To provide cadres with an understanding of reported radical issues, the Regional Branch of Palu is provided its cadres in tarbiyah, as a form of strengthening by tidying up the internal institutions. From all the efforts made, Wahdah Islamiyah Palu has plans to utilize social media as part of the syiar and publish all activities carried out offline as an effort to build a good image ${ }^{34}$.

This step has started well even though there are still some obstacles. The management of Wahdah Islamiyah Regional Branch of Palu also understood that in the modern era like today, modern communication media is important to be used because of the high flow of information circulating causes messages be quickly delivered. Exposure to communication media is an important aspect that must be considered, because it cannot be denied that with the development of

\footnotetext{
${ }^{33}$ Hassim, "Hijab and the Malay-Muslim Woman in Media."

${ }^{34}$ Nuredayu Omar, "Communication Competence during the Preparation Phase of the Direct Selling Communication Activities," Procedia - Social and Behavioral Sciences 155, no. October (2014): 22835, https://doi.org/10.1016/j.sbspro.2014.10.284.
} 
communication technology, the Muslims will inevitably be highlighted and exposed to the media especially with radical labels that have been embedded in Muslim symbols ${ }^{35}$. Wahdah Islamiyah Regional Branch of Palu itself proves the efficiency of the use of modern communication media when the issue of how to dress for female cadres related to the color combination becomes the highlight of the matter.

Using these steps, Wahdah Islamiyah has tried to rebuild the image of the Muslim community, especially those who are affiliated with Islamic organizations and wear Islamic symbols on a daily basis. Such approach reopens the opportunity to let go of negative images and radical labels on Islamic symbols and rebuild the image of Islam as a guide to daily life by providing high-intensity exposure directly to the community 36 .

\section{H. Conclusions}

Wahdah Islamiyah, especially Regional Branch of Palu, already has an awareness of the importance of using modern media. The pattern of media utilization carried out by Wahdah Islamiyah Palu has also been well organized, although in its application there are still several obstacles. $D a$ 'wah is carried out by the organization through social media is packaged in a good presentation, supported by cadres who qualified enough in design aspects. It's just that Wahdah Islamiyah Palu does not have many cadres who have good journalistic skills, so many published content does not properly use journalistic rules.

In responding to the threat of radicalism, Wahdah Islamiyah which has been accused several times as a radical movement by the media, has a neatly intertwined specific strategies. This strategies follow an inverted triangle pattern, where more reaction efforts are made in the central Wahdah Islamiyah. The strategies was carried out to unite opinions and avoid the impression that the organization is an aggressive organization in response to news, for example in dealing with the stigma of black outwear who are often associated with radical movements.

\footnotetext{
35 Hassim, "Hijab and the Malay-Muslim Woman in Media"; Khairil, "The Transformation of the Symbolic Meaning of Radicalism in Acts of Terrorism Post-Conflict in Poso Central Sulawesi."

${ }^{36}$ Rosninawati Hussin et al., "Islamic Representation in Television Advertising and Its Impact on Modern Malay Muslim Women," Procedia - Social and Behavioral Sciences 211 (2015): 890-95, https://doi.org/10.1016/j.sbspro.2015.11.117.
} 
Wahdah Islamiyah's Counter-Radicalism Strategy Through The New Media Network in Da'wah Development of Palu City

The steps taken by Wahdah Islamiyah's members are aimed at releasing various bad images and radical labels that often stick to Islamic symbols that are often worn by members of Wahdah Islamiyah, such as veils and black clothing. By applying an approach that directly opposes stigma in society by acting unlike what is believed by the community, members of Wahdah Islamiyah rebuild the negative image of the Islamic symbol as the way of Islam seen as the way of everyday life in the eyes of society.

\section{BIBLIOGRAPHY}

Alexandru, Pompiliu. "A Semiotic Analysis of the Expression of Antithetical Emotional States." Procedia - Social and Behavioral Sciences 149 (2014): 3136. https://doi.org/10.1016/j.sbspro.2014.08.174.

Arifin, Anwar. Dakwah Kontemporer Sebuah Studi Komunikasi. Yogyakarta: Graha Ilmu, 2011.

Effendy, O. U. Ilmu Komunikasi : Teori Dan Praktek. Bandung: Remaja Rosdakarya, 2011.

Hassim, Nurzihan. "Hijab and the Malay-Muslim Woman in Media." Procedia Social and Behavioral Sciences 155, no. October (2014): 428-33. https://doi.org/10.1016/j.sbspro.2014.10.317.

Hussin, Rosninawati, Sofia Hayati, Siti Nubailah, and Mohd Yusof. "Islamic Representation in Television Advertising and Its Impact on Modern Malay Muslim Women." Procedia - Social and Behavioral Sciences 211 (2015): 89095. https://doi.org/10.1016/j.sbspro.2015.11.117.

Khairil, Muhammad. "Pluralisme, Toleransi Dan Budaya Komunikasi Ummat Beragama." Jurnal Inspirasi MKDU Untad, no. 3 (2007): 25.

Khairil, Muhammad. "The Transformation of the Symbolic Meaning of Radicalism in Acts of Terrorism Post-Conflict in Poso Central Sulawesi." In International Conference on Democracy, Accountability and Governance, 282-89, 2017.

Khairil, Muhammad, Muhammad Nur Ali, Sharifah Zarina Syed Zakaria, Kadir Arifin, and Muhammad Rizal Razman. "Mass Media Coverage on Terrorism in Order to Achieve Peace and Justice According to the World Agenda of Sustainable Development Goals (SDGs)." INFORMATION 20, no. 7 (A) (2017): 4935-40.

Khairil, Muhammad, Emrizal, Razman, Muhammad Rizal, Zuliskandar Ramli, and Kadir Arifin. "Understanding Terrorism Based On Radicalism Idea In Order To Avoid Instability For Achieving Environmental Peace And Justice The Sustainable Development Goals (SDGs)." Journal of Food, Agriculture \& Environment 15, no. I (2017): 48-51.

Kurt, Hanifi. "Acritical Review to the Media Which Constructed in Media Literary Course in Secondary Education." Procedia - Social and Behavioral Sciences 174 (2015): 711-19. https://doi.org/10.1016/j.sbspro.2015.01.606. 
Nata, H. Abuddin. Peta Kerangka Pemikiran Islam Di Indonesia. Jakarta: Raja Grafindo Persada, 2001.

Omar, Nuredayu. "Communication Competence during the Preparation Phase of the Direct Selling Communication Activities." Procedia - Social and Behavioral Sciences 155, no. October (2014): 228-35. https://doi.org/10.1016/j.sbspro.2014.10.284.

Rais, Amin. Cakrawala Islam. Bandung: Mizan, 1999.

Rakhmat, Jalaluddin. Psikologi Komunikasi. Bandung: Rosdakarya, 2015.

Rusman. Pembelajaran Berbasis Teknologi Informasi Dan Komunikasi. Jakarta: RajaGrafindo Persada, 2015.

Suciu, Lavinia, and Simona Simon. "Informing Strategies: Building the Communication Framework." Procedia - Social and Behavioral Sciences 197, no. February (2015): 1246-49. https://doi.org/10.1016/j.sbspro.2015.07.392.

Törnberg, Anton, and Petter Törnberg. "Muslims in Social Media Discourse: Combining Topic Modeling and Critical Discourse Analysis." Discourse, Context and Media 13 (2016): 132-42. https://doi.org/10.1016/j.dcm.2016.04.003.

Wahjuwibowo, Indiwan Seto. Terorisme Dalam Pemberitaan Media. Yogyakarta: Deepublish, 2015.

Warren, Saskia. "Placing Faith in Creative Labour: Muslim Women and Digital Media Work in Britain." Geoforum 97, no. October (2018): 1-9. https://doi.org/10.1016/j.geoforum.2018.10.003.

Weaver, Iain S., Hywel Williams, Iulia Cioroianu, Matthew Williams, Travis Coan, and Susan Banducci. "Dynamic Social Media Affiliations among UK Politicians." Social Networks 54 (2018): 132-44. https://doi.org/10.1016/j.socnet.2018.01.008.

West, Keon, and Joda Lloyd. "The Role of Labeling and Bias in the Portrayals of Acts of 'Terrorism': Media Representations of Muslims vs. Non-Muslims." Journal of Muslim Minority Affairs 37, no. 2 (2017): 211-22.

Yusoff, Kamaruzaman. "Islamic Radicalism in Malaysia: An Overview" 5 (2010): 2326-31. https://doi.org/10.1016/j.sbspro.2010.07.458. 